\title{
The Credibility of Traditional and Online Media for the Promotion of Tourism in the Contemporary Tourism Marketing Environment in Durban South Africa
}

\author{
Dr. Douglas Chiguvi ${ }^{1}$; Dr. Elvis Madondo ${ }^{2} \&$ Dr. Ruramayi Tadu ${ }^{3}$ \\ ${ }^{1}$ Senior Lecturer: Marketing Programmes, Entrepreneurship Department, BA ISAGO University P. Bag 149, Gaborone, \\ Botswana \\ ${ }^{2}$ Faculty of Management Sciences, Durban University of Technology, P O. Box 1334, Durban 4000, South Africa \\ ${ }^{3}$ Vice President - Academic Affairs \& Research, BA ISAGO University, P. Bag 149, Gaborone, Botswana \\ Correspondence: Dr. Douglas Chiguvi, Senior Lecturer: Marketing Programmes, Entrepreneurship Department, BA \\ ISAGO University P. Bag 149, Gaborone, Botswana.
}

Received: March 25, 2019

doi:10.11114/bms.v5i4.4596
Accepted: September 5, 2019

Online Published: October 30, 2019

URL: https://doi.org/10.11114/bms.v5i4.4596

\begin{abstract}
The main purpose of study is to analyse the credibility of traditional and online media for the promotion of tourism in the contemporary tourism marketing environment in Durban South Africa. Explanatory research design was employed and the questionnaire was used to collect the data. The study findings revealed that traditional media and online media are more or less equally competitive for the promotion of tourism. The study also revealed that international visitors have a positive attitude towards online media than traditional media while domestic tourists have a positive attitude towards traditional media than online media. Traditional media was revealed to be highly credible than the general perception of the people and it is a lot more credible than online media. The survival of traditional media is not threatened by online media and traditional media is still working well alongside online media. The study concluded and recommended that tourism marketers and authorities need to come to terms with traditional media and online media coexistence. There is no need to rely on one media to do it all. Where traditional media lacks, online media must be there to make up the difference and enhance the tourist's experience.
\end{abstract}

Keywords: traditional media, online media, advertising, tourism promotion

\section{Background of the Study}

South Africa is a leading tourist destination in Africa and one of the most visited destinations in the world as it has a wide array of attractions coupled with developed cities (Statistics South Africa, 2016). Since the end of apartheid in 1994, South Africa has improved its tourism position in the world from the $52^{\text {nd }}$ most visited destination to the $17^{\text {th }}$ most visited tourism destination in 2005. Cape Town, Durban and Gauteng are the most popular tourism destinations for international tourists. However, even though Durban is not as popular as Cape Town, the former has more to offer and a great potential to grow (South African Tourism 2011: 15). According to Cooper (2012: 265) tourism was at the forefront of the changes that took place in South Africa in an attempt to create 'a new South Africa' in this post-apartheid period. Tourism has helped to boost the economy and create a sense of national pride. A significant change was the devolution of tourism powers from the central government to the nine South African provinces. Considerable planning activities are taking place at provincial levels as the provinces get to grips with their new tourism roles. One of the nine provinces is KwaZulu-Natal, which is covered in this study. Provinces are responsible for tourism product or service development and marketing for both international and domestic markets (cooper and Hall, 2016). This study is confined to the province of KwaZulu-Natal as an equal contributor to the promotion of tourism in Durban.

According to Statistics South Africa (2016) KwaZulu-Natal (KZN) is the country's domestic tourism leader, increasingly on the 'must-do, must see' lists of prospective travellers, and highly popular among international visitors. This province, on the eastern side of South Africa, is bordered by the Indian Ocean to the east and the great escarpment of the Drakensberg Mountains, separating it from the mountainous kingdom of Lesotho, to the west. The province is $94361 \mathrm{~km}^{2}$ in area, covering almost 8\% of the country's geographic area. KwaZulu-Natal boasts two World Heritage 
Sites: Ukhahlamba-Drakensberg Park and iSimangaliso Wetland Park. It also boasts two of South Africa's major natural harbours at Richards Bay and Durban. The province is well known as the Kingdom of the Zulu, and represents a blend of Indian, African and European cultures. The province offers a relaxed lifestyle, with access to virtually every major type of recreation, sporting, and cultural facility (Seymour, Stolk and Kohler 2009: 1). It has 8 well defined tourism destinations, sites and nodes in which tourism-specific development projects have been successful and new ones are still encouraged. These are: Zululand, South Coast, Durban, North Coast, Battlefields, Pietermaritzburg and Midlands, Elephant Coast, and Drakensberg. The Tourism KwaZulu- Natal Strategy (2014: 7) indicates that the KwaZulu-Natal Tourism Authority (KZNTA), operating as Tourism KwaZulu-Natal is responsible for promoting tourism within the province. The major tourist destinations in the province are found in the Durban City. The sector is largely dominated by private organisations and a few public owned organisations such as Leisurenet and Kersaf. Seymour et al. (2009: 19) state that the provincial government of KwaZulu-Natal plays a critically important role in the development and promotion of tourism in the province. The private sector also provides a significant impetus towards the development and promotion of tourism within the province.

\section{Literature Review}

\subsection{Definition of Tourism}

Statistics South Africa (2011: 3) define tourism as, all the activities undertaken by individuals travelling to places away from their usual environment, and staying there for business, leisure and other purposes. Hoyle (2002: 2) states that tourism is a temporary movement of people outside their normal place of residence and work, together with the facilities provided to cater for those visits and the activities undertaken during the stay in those visited places. A person's usual environment refers to all the places frequently visited by that individual, and the areas around his or her residential place. The United Nations World Tourism Organisations (UNWTO) define a visitor, to distinguish him/her from a tourist as a person travelling to a place away from his/her usual environment for a period of less than one year and whose main purpose is not to undertake a remunerated activity from the place of visit. Pike (2016: 8) argue that there is no universally accepted definition of tourism to date. Leading tourism academics such as Page and Connell (2009 cited in Pike 2016: 8) point out that different definitions of tourism are offered in most tourism textbooks. Cooper and Hall (2017: 13) argue that the key concepts are temporary, voluntary and mobility. They add that if a person is away from his/her home environment on an involuntary basis, for example as a result of natural disaster, war, or other crisis, he/she is usually called a 'refugee'. If individuals have been forced into cross-border sexual or labour slavery, they may be termed 'trafficked persons' and not tourists. A holistic approach where effort was made to capture the whole essence of tourism states that, Tourism is the study of people away from their usual habitat, of the industry which responds to their needs, and of the impacts that those people and the industry have on the host's economic, socio-cultural, and physical environments (Leiper 1979: 394). Because of the holistic nature of this definition, it is therefore the one adapted in this study.

Traditionally, tourism has been viewed from the demand perspective as being hedonic (pleasure seeking). However, this perspective does not encompass other categories of temporary visitors to a destination. Besides travelling for general pleasure, many other types of tourism have been documented. These include travel for conferences, business, medical procedures, sport, exhibition, gambling, sex and romance, visiting relatives and friends, spiritual pilgrims, gastronomy, educational field trips, and art (Pike 2016: 9). According to Nielsen (2001: 23) the best definition of tourism is the one that suits the organisation or individual seeking to define tourism. It can be argued that any definition of tourism depends ultimately on the purpose and perspective requiring explanation. The final word on tourism definitions is that the definitions change with time and depend on different circumstances requiring an explanation.

\subsection{The Promotion of Tourism}

According to Pomering, Noble and Johnson (2011: 962) promotion is the means by which organisations attempt to remind, persuade and inform customers about brands or products that they sell. In the tourism industry, promotion is the most visible factor of the '4' Ps in the marketing mix and the other three Ps refer to Product, Place and Price. Bujdoso, Manhas, David and Nedelea (2013: 37) supplement that tourism is a type of service to which the marketing mix can be applied to and promotion is an essential key element in this industry. Burrow (2006: 4069) argues that the type of communication to be used depends on the nature of the product or service, and the characteristics of the target market. As a result, the promotion of tourism destinations implies a particular form of communication consisting of various ways of transmission of information and messages meant to inform the potential tourist about destinations' characteristics and the component elements of tourism products offered/available. According to Dickman and Maddock (2000: 120) tourism can be promoted when there is effective communication with the potential or actual tourist.

According to Liu (2000: 8) tourism products and services are ideal for promotion on the Internet because tourism is an information-intensive industry. The internet is the most efficient and effective means in information exchange globally. 
It can facilitate the distribution and promotion of tourism products and potentially enable tourism enterprises and destinations to compete from the same level (Howison et al., 2014: 271). However, this does not mean that traditional media is obsolete in promoting tourism. There are also benefits still available in using traditional media for the promotion of tourism. Hartl (2002: 16) observes that modern marketing approaches (Internet based) are more developed in the fast moving consumer goods (FMCG) industry than in tourism marketing. There is probably a gap in what is stipulated in the literature and how these modern marketing approaches are being practically applied in tourism marketing.

Tourism, as a place product, includes all elements offered by a destination to tourists, including the cultural, physical and social environments. It also includes the "touristic" components of tourism supply such as transport and lodging facilities, attractions, and other travel related services. Tourism is fragmented in that, though the tourist views a holiday as a complete ":experience", it is sold "in bit" in the market place as tours, meals, beds, seats and so on, by a plethora of different suppliers operating independently of one another. Moreover, no one agency can deliver or control content about tourism products as the promotion of a tourism destination is shared by other organisations such as regional tourism boards, tourist information centres, and national tourism organisations.

Given this nature of tourism destination product, online media provides an effective means of a sustainable electronic "infrastructure" that can establish a multi-lingual and comprehensive destination web site. The site can present potential and existing tourists with updated information from different sources, in all aspects of tourism - transportation, tourist attractions, tour operators, accommodation, travel agency, leisure and shopping facilities (Van and Tu, 2016: 222). In comparison with traditional media, in an attempt to get relevant information, a tourist needs to get a brochure form a travel agent, get a guide book from a bookshop, and contact the national office of the destination to get promotional literature. While a maintained and properly constructed web site can supply right-to-the-minute information, printed literatures are often outdated (Kardaras, Krakostas and Mamakou, 2013: 2331). However, even online sources of information can provide outdated information if not properly updated. Printed literature can also be updated in the same way although the process is not that efficient. This implies that whether it is online or traditional media, the source of information needs to be constantly updated in order to supply relevant information.

\subsection{Media Credibility}

According to Kim (2016: 93) the concept of media credibility has a long history within marketing, public relations, and communication. One area which scholars have been interested in is source credibility, which looks at specific organisations or individuals (the source) that deliver the information and the perception of the public on the credibility of that brand or individual. Another dimension of credibility which is also covered in this study is not based on the source, but on the medium through which the communication occurs. Medium credibility studies, in other words, examine specific platforms such as newspapers, the Internet, or television, to understand the perceptions of the public on credibility (Kim 2016: 93). The concept of credibility is composed of multiple dimensions perceived and evaluated by individuals when interacting. Essentially, these dimensions are the factors considered to be important and influential in developing the perception of credibility. The main dimensions that have historically been used to reflect credibility in both medium and source studies include expertise, completeness, accuracy, trustworthiness, believability, community affiliation, and fairness.

\subsection{New Media Credibility}

As noticed from the above discussion, credibility was historically considered in a single context, such as being medium, source, or organisation. The advent of new media which seems to combine platforms and sources into a unique presentation of information to the target audience prompted Kim (2016: 95) to suggest that credibility should be viewed as a concept of both medium and source combined together. This is especially true in the digital media environment of today, particularly the case of social media. In this world of social media, dimensions of source credibility such as authenticity, affinity, and trustworthiness are merged with medium dimensions such as believability, accuracy and fairness. All these dimensions play a pivotal role in the individuals' perception of brand credibility in social media, which holds the ultimate power to break or make key stakeholders' relationship with the brand. Therefore, it is pivotal that practitioners use social media to communicate in ways that support and enhance individuals' perception of an organisation's credibility in order to build and maintain relationships with the audiences. Kim (2016: 94) clearly states that in social media, with its distinct focus on two-way communication and building relationships, credibility is critically tied to the extent of effectiveness of relationship-building activities.

\subsection{The Credibility of Traditional Media}

The increase in ad clutter in traditional advertising media such as newspapers, radio and TV has had negative effects on both the advertising content and the media. In 1997, it was found out that increased advertising levels in magazines reduce the effectiveness of each ad, as well as the profitability and circulation of magazines (Dahlen and Edenius 2007: 
34). Traditional advertising media have also suffered from less favourable evaluations and reduced credibility. It was argued that reactions to the advertised message are more favourable when the ad is placed in non-traditional medium than in traditional medium where consumers can readily identify the advertised message as advertising. However, Seymour et al. (2009: 18) revealed that the most important reasons for South Africans who considered visiting KwaZulu-Natal as a tourism destination in 2008 were that they saw an advertisement in the magazine, saw a television commercial aid or red an article about the region.

The ongoing observation has shown that newspapers and radio, though their position in promoting tourism is yet to be established, they are highly credible than other media outlets such as television and online media. Consumers often credit the information they hear or see in the radio and newspaper respectively. Brochures and television are also credible sources of information in the tourism environment though the information conveyed by these outlets can sometimes be limited in space and time.

\section{Research Design}

This study followed an explanatory research design. This study adopted a mixed method research approach. The quantitative approach was used primarily to engage with respondents who were identified as tourists, as access, time and type of responses had to be considered to ensure the best possible outcomes. The qualitative approach was important to apply to the tourism marketers and authorities to determine data rich responses which this study relied heavily upon especially in terms of how traditional and online media are used in advertising their businesses. A survey strategy was employed and was considered appropriate as this study is at the foundational stages of assessing the credibility of traditional and online media, and it intends to make inferences about the tourism population in Durban.

\subsection{Target Population}

For this study, two populations were investigated. These were tourism marketers in Hotels, Travel Agents, Durban Tourism and KwaZulu-Natal Tourism (TKZN) department, and the tourists (local and foreign nationals) visiting the tourism destinations in Durban. According to Tourism KwaZulu-Natal (2014: 4) there is an averaged 847146 tourists from outside South Africa who visit KwaZulu-Natal annually, and 7100000 domestic visits to Kwazulu-Natal. This gives a total of 7947146 tourists which constitutes the population for this study. The populations of this study therefore was made up of 7947146 tourists and tourism marketers in Travel Agents, Hotels, TKZN and Durban Tourism Authority. These populations were considered cardinal to the topic under study. The inclusion of the Travel Agents, Hotels and KZN Tourism Departments were of vital importance towards meeting with the objective of the study. The study employed a non-probability sampling technique. Non-probability sampling was employed in the form of quota and convenience sampling. Quota sampling was used in order to select the tourists for this study. This method relies on the personal judgement of the researcher and the elements of the population have no equal opportunities for selection (Howitt and Cramer (2010:44). In this study, the tourism population visiting KwaZulu-Natal was sampled along the following quota control characteristics:

- Country of residence, to match the population which has people from many different countries.

- Race, to include the four racial groups that exist in the tourism population of KwaZulu-Natal.

- Age and gender balance, to proportionally represent different age groups and gender as assumed to exist in the population.

- Activity undertaken by the tourist in KwaZulu-Natal, to appeal to people of different interests.

This quota sampling was based on the statistical characteristics of the tourists visiting KwaZulu-Natal as revealed in Tourism KwaZulu-Natal (2014: 7).

Convenience sampling, a form of non-probability sampling was also employed in this study and it refers to the ease with which participants can be obtained by the researcher (Gravetter and Farzano, 2011: 151). As a result, respondents from the tourism population were chosen at the convenience of the researcher at the selected data collection points in Durban such as the Gateway Mall, beach front, and the Durban station. Sekaran and Bougie (2010:296) state that an appropriate sample size must range between 30 and 500 respondents. The study applies a formula developed by Israel (1992) in order to determine an appropriate sample size of the tourist population as follows:

$$
\mathrm{n}=\frac{N}{1+N(e)^{2}}=\frac{7947146}{1+7947146(0.05)^{2}}=\frac{7947146}{19867.8675}=399.999=400
$$

Where $\mathbf{n}=$ sample size, $\mathbf{N}=$ Population sample, and $\mathbf{e}=$ sampling error or level of precision

Therefore, the sample size was 400 tourists. Furthermore, this was complimented by tourism marketers from travel agents, hotels and the tourism department of TKZN and Durban Tourism, of which the researcher interviewed 7 in order 
to get in-depth responses to key issues pertinent to this study. The opinions of the tourists, travel agents, hotels and the tourism authorities were obtained, leading to a complete picture of all attitudes and opinions relating to the issue under investigation.

\subsection{Data Collection Method}

Questionnaire was used as research instrument for collecting quantitative data from the tourists and structured in-depth interviews were employed to collect qualitative data. Questionnaires were regarded as the most suitable instrument for data collection in this study because it allows a substantial amount of information to be obtained from the tourists. Given a larger number of respondents targeted and their geographical dispersion, a questionnaire is considered to be the most cost-effective method. The questionnaire mainly contained Likert-scale type questions in order to solicit information on individual perceptions. This was done on a 5 point scale that ranged from strongly disagree (SD) to strongly agree (SA). Structured in-depth interviews were employed to collect qualitative data. Structured in-depth interviews were used to collect qualitative data from tourism marketers in KwaZulu-Natal. Travel Agents, Hotels and the Tourism Departments of KZN and Durban Tourism were considered as key informants on the promotion of tourism in this region. As such, two marketing managers in two different Travel Agents in KZN, two marketing managers in two different Hotels, one marketing manager from Durban Tourism, and two officials in TKZN were interviewed. The researcher used purposive or judgmental sampling to recruit the respondents. The interviews were guided by an interview guide and the questions in the interview guide were at times modified on grounds of the respondents' reactions. In-depth interviews enabled the researchers to seek greater clarification from the respondents.

\subsection{Data Analysis}

Quantitative data from the tourists was analysed following quantitative procedures and the data from tourism marketers was analysed using qualitative procedures. The collected data was analysed using the Statistical Package for Social Sciences (SPSS version 23). The results will present the descriptive statistics in the form of graphs, cross tabulations and other figures for the quantitative data that was collected. Inferential techniques include the use of correlations and chi square test values; which are interpreted using the p-values. In total, 400 questionnaires were distributed and 298 were returned, giving a $74.5 \%$ response rate. Validity was also addressed through conducting a two factor analysis and a pilot study. The researcher also employed a code system where by a person involved in the investigation was identified numerically and even the organisation name was not mentioned.

\section{Data Findings}

Data findings for both quantitative and qualitative research approaches were analysed and discussed.

\section{Quantitative Analysis}

Table 4.0 reflects the Cronbach's alpha score for all the items that constituted the questionnaire.

Table 4.0. Cronbach's alpha score

\begin{tabular}{lcc}
\hline & N of Items & Cronbach's Alpha \\
\hline Credibility of traditional media in promoting tourism & 10 & 0.749 \\
The benefits of traditional media versus online media & 7 & 0.786
\end{tabular}

The reliability scores exceed the recommended Cronbach's alpha value of 0.70 . This indicates a degree of acceptable, consistent scoring of the research instrument. The researchers also tested KMO to examine the sufficiency and suitability of the data. The requirement is that Kaiser-Meyer-Olkin Measure of Sampling Adequacy should be greater than 0.50 and Bartlett's Test of Sphericity less than 0.05. Results in table 4.1 shows that in all instances, the conditions are satisfied which allows for the factor analysis procedure.

Table 4.1. KMO and Bartlett's Test

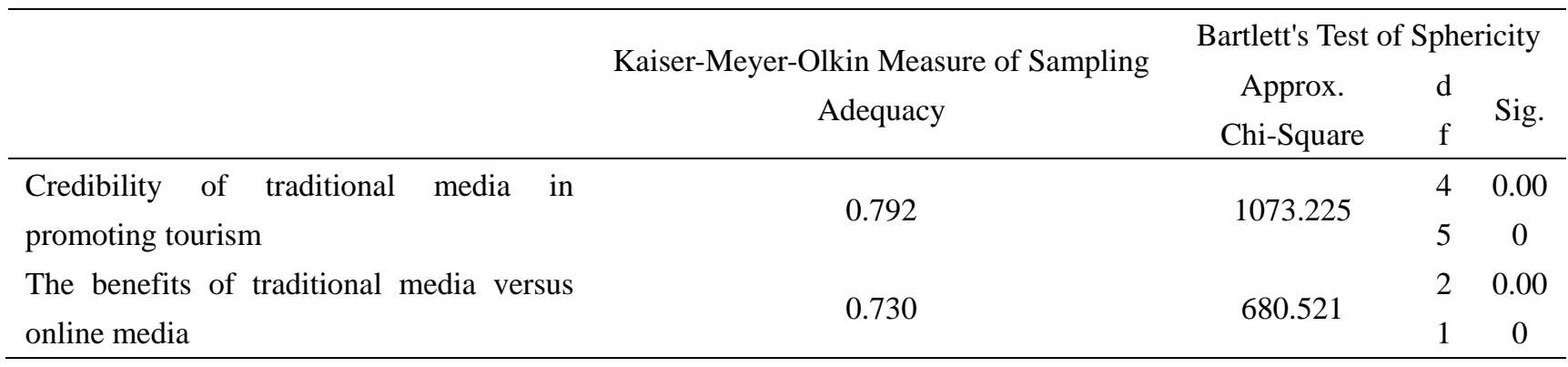


All of the conditions are satisfied for factor analysis. That is, the Kaiser-Meyer-Olkin Measure of Sampling Adequacy value should be greater than 0.500 and the Bartlett's Test of Sphericity sig. value should be less than 0.05 . This shows that the indicators of the constructs belonged together and have sufficient data to conduct the study.

\subsection{The Credibility of Traditional and Online Media in the Promotion of Tourism}

This section looks at the credibiity of traditional media for the promotion of tourism. The main objective of the study was to examine the credibility of traditional and online media in the contemporary tourism marketing environment. Table 4.2 and Figure 4.0 illustrate the scoring patterns of the results obtained.

Table 4.2. Credibility of traditional and online media in the promotion of tourism

\begin{tabular}{|c|c|c|c|c|c|c|c|}
\hline & & Online & $\begin{array}{c}\text { Traditio } \\
\text { nal }\end{array}$ & $\begin{array}{l}\text { Mann- } \\
\text { Whitne } \\
\text { y U }\end{array}$ & $\begin{array}{l}\text { Wilcox } \\
\text { on W }\end{array}$ & Z & $\begin{array}{l}\text { Asymp. } \\
\text { Sig. } \\
\text { (2-tailed) }\end{array}$ \\
\hline $\begin{array}{l}\text { Traditional media is more believable than } \\
\text { online media. }\end{array}$ & B2.1 & 3.48 & 3.80 & 8614.50 & $\begin{array}{c}28117.5 \\
0\end{array}$ & -2.059 & 0.039 \\
\hline $\begin{array}{l}\text { I do trust information obtained via traditional } \\
\text { media than via online media. }\end{array}$ & B 2.2 & 3.48 & 4.01 & 7376.50 & $\begin{array}{c}26879.5 \\
0\end{array}$ & -3.799 & 0.000 \\
\hline $\begin{array}{l}\text { Advertised messages are more credible when } \\
\text { the ad is placed in traditional medium than in } \\
\text { non-traditional medium. }\end{array}$ & B2.3 & 3.53 & 4.05 & 7132.00 & $\begin{array}{c}26438.0 \\
0\end{array}$ & -4.159 & 0.000 \\
\hline $\begin{array}{l}\text { Traditional media provides enough } \\
\text { information (completeness) for decision } \\
\text { making. }\end{array}$ & B2.4 & 3.34 & 3.69 & 8234.00 & $\begin{array}{c}27737.0 \\
0\end{array}$ & -2.504 & 0.012 \\
\hline $\begin{array}{l}\text { Traditional media is more reliable and } \\
\text { accurate compared to online media. } \\
\text { B2.5 }\end{array}$ & & 3.36 & 3.88 & 7280.50 & $\begin{array}{c}26783.5 \\
0\end{array}$ & -3.975 & 0.000 \\
\hline $\begin{array}{l}\text { I am comfortable to use online media to } \\
\text { source information. } \quad \text { B2.6 }\end{array}$ & & 3.60 & 2.74 & 6388.00 & $\begin{array}{c}11539.0 \\
0\end{array}$ & -5.177 & 0.000 \\
\hline $\begin{array}{l}\text { Traditional media is more dependable for up } \\
\text { to date information compared to online media } \\
\text { for tourism information. B2.7 }\end{array}$ & & 2.91 & 3.53 & 7161.50 & $\begin{array}{c}26664.5 \\
0\end{array}$ & -4.075 & 0.000 \\
\hline $\begin{array}{l}\text { I use traditional media to verify online media } \\
\text { for tourism } \\
\text { B2.8 }\end{array}$ & & 2.87 & 2.82 & 9670.50 & $\begin{array}{c}14821.5 \\
0\end{array}$ & -0.405 & 0.686 \\
\hline $\begin{array}{l}\text { I use online media to verify traditional media } \\
\text { for } \quad \text { tourism } \quad \text { information. } \\
\text { B2.9 }\end{array}$ & & 3.21 & 2.86 & 8120.50 & $\begin{array}{c}13271.5 \\
0\end{array}$ & -2.670 & 0.008 \\
\hline $\begin{array}{l}\text { I prefer to use online media in order to access } \\
\text { the testimonials of other tourists. } \\
\text { B2.10 }\end{array}$ & & 3.44 & 2.83 & 7199.00 & $\begin{array}{c}12350.0 \\
0\end{array}$ & -3.999 & 0.000 \\
\hline
\end{tabular}

The table 4.2 reflects the mean scores for the statements. The means were tested between the two groups, with $\mathrm{p}<0.05$ considered as significant. To determine whether the scoring patterns between the groups were similar, a Mann Whitney test was done. The null hypothesis claims that there is no difference in the central measure. The results are shown in the table 4.2. The highlighted sig. values (p-values) are less than 0.05 (the level of significance), it implies that there were significant differences between the groups for these statements. 


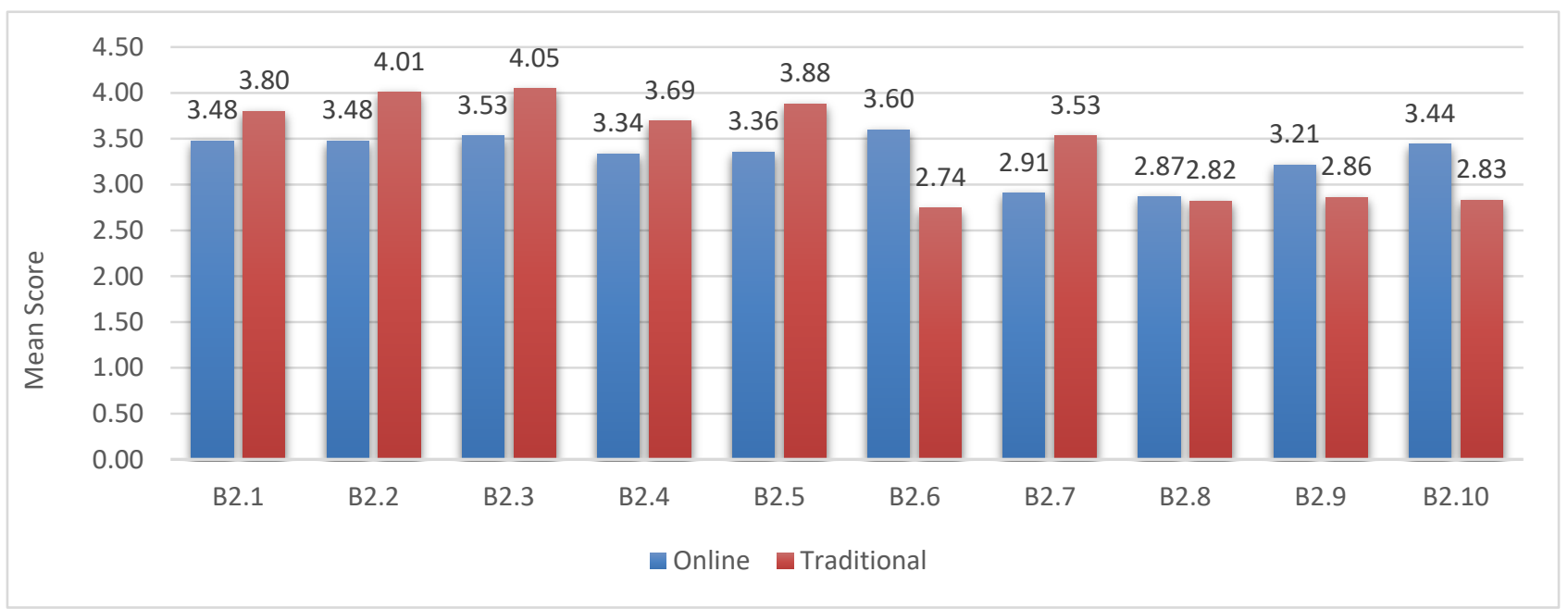

Figure 4.0. Credibility of traditional and Online media in the promotion of tourism

The following patterns are observed:

- Some statements show (significantly) higher levels of agreement whilst other levels of agreement are lower (but still greater than levels of disagreement).

- For some statements, online scores are higher whilst this is reversed for other statements.

- The significance of the differences between the groups is tested and shown in the table.

Significantly higher levels of agreement were noticed on the statements: Advertised messages are more credible when the ad is placed in a traditional medium than in non-traditional medium (mean score 4.05), I do trust information obtained via traditional media than via online (mean score 4.01), traditional media is more reliable and accurate compared to online media (mean score 3.88), and traditional media is more credibile than online media (mean score 3.80). Factor analysis show that these statements form a sub-theme. These findings reveal that traditional media is still more credible for toursim information in this digital age. The results contradict with (Dahlen and Edenius 2007: 34) assertion that traditional advertising media have suffered from less favourable evaluations and reduced credibility. The reason for the contradiction is partly due to the differences in the industry context in which the studies were conducted. The findings suggest that though credibility of traditional media might have reduced over the past, it is still considered more credible than online media for tourism information.

Factor analysis also shows that the following three statements form a sub-theme: I am comfortable to use online media to source information (mean score 3.60), I use online media to verify traditional media for tourism information (mean score 3.21), and I prefer to use online media in order to access the testimonials of other tourists (mean score 3.44). For these statements, online scores were higher than traditional media scores. This suggests that other tourist consider online media to be credible for the variables under investigation. The results associate with Kim's (2016: 94) assertion that credibility is critically tied on the effectiveness of relationship-building activities such as on social media.

\subsection{Qualitative Analysis}

The qualitative data was transcribed verbatim to guide the discussion. Relevant quotes from the data obtained from structured interviews were used to support this discussion.

\subsection{Tourism Marketers' Media Usage Pattern}

The participants were asked to elaborate on how they are using traditional media and online media. The following sub themes were identified from the responses.

\subsection{A Ten Year Trend Review}

All participants indicated that they use both traditional media and online media for the promotion of tourism and their media usage patterns have changed in the last 10 years. There has been an increase in the use of online media and neither a decrease nor an increase in the use of traditional media. They further elaborated that:

Definitely there has been a shift to an increase in the use of online media, but not a shift on it being more effective. Traditional media mainly changed in terms of content and not in terms of how much of it do we use, there has been no change in the last 10 years. Traditional media still works for us but how the content is packaged has changed. 
To summarise this trend, there has been an increase in the usage of online media coupled with no change in the use of traditional media. The participants indicated that the increase in the use of online media is not tantamount to the increase in its effectiveness. This pattern disagrees with Loda (2014: 306) who states that the digital revolution has already changed almost everything about how business is conducted in the tourism industry. It is important to note that some things were not changed such as the use of traditional media in the tourism sector in KwaZulu-Natal. The uptake of digital revolution was much slower in South Africa than other first world countries. This is the reason to why the response from the tourism operators differs from other authors studies such as Loda (2014).

Still on the media usage pattern of the tourism marketers, the following sub-theme was identified to reflect the state of media usage.

\subsection{The Media Used in Promoting Tourism in KZN}

The findings reflect that both traditional media and online media are being used in promoting tourism. Tourism authorities indicate that they still use more of traditional media than online media. This did not agree with the travel agents and hotels who indicated that they use more of online media than traditional media. Travel agents and hotels elaborated that:

We use online media more frequently because we own the resources to do so.

Tourism authorities pointed out that:

TKZN has a website and we are getting increasingly active on Instagram, Twitter, and Facebook but we are still using more of traditional media than online media.

The findings support Goyal and Sharma's (2013: 45) assertion that possessing a web site or a web portal in the tourism industry has become a basic for promoting tourism services and products. The responses also associate with Hudson and Thal's (2013: 157) who mention that tourism marketers are considerably using social media to engage with actual and potential tourists throughout the decision making journey.

The responses also indicate that traditional media is used to a greater extent and the print medium (brochures and magazines) are mainly used. The results do not resonate with the assertion by Chao et al. (2012: 12) who claim that the rise of online advertising as one of the most prominent promotion vehicles has prompted business organisations around the world to strategically shift their focus to online media. Tourism marketers did not shift their focus from traditional media but they increased their use of online media whilst maintaining the trend on traditional media.

Tourism Kwazulu-Natal (TKZN) uses a lot of brochures and these are housed at a number of different tourist information offices such as at Ushaka Marine World, King Shaka International Airport, Kokstard, Cape Town International Airport, O. R Tambo International Airport, Montrose and a number of magazines are being used as TKZN has partnerships with publishers. Radio and TV are also used to market the destination and as well as various events.

While appreciating that traditional media was to some extend affected, the transformation was not as massive as predicted. The tourism sector is a unique industry where the use of traditional media is still massive. The results do not resound well with Sturgis (2012: 1) who highlights that traditional advertising media have been massively shaken by the internet revolution which transformed the environment in which they all operate. The ongoing discussion on this sub-theme has clearly revealed that tourism authorities have a different media usage pattern from travel agents and hotels. Hotels and travel agents they tend to use more of online media than traditional media and among the reasons for this was that online media is more affordable than traditional media, given their small size. Tourism authorities use more of traditional media than online media. The following sub-theme was also identified.

\subsection{The Preferred Media for Conveying Marketing Messages}

The majority of the participants highlight that they have no premeditated media preference, but their media choice is influenced by factors such as the target market to be reached, the preference of the tourists, and the objective to be achieved. However, all travel agents indicated that they prefer online media because of their small size and its affordability. Hotels and tourism authorities indicate that they prefer to use both traditional media and online media as long as they can get the results.

\subsection{The Credibility of Traditional Media in the Contemporary Tourism Marketing Environment}

The following section reveals the credibility of traditional media in promoting tourism in this digital age where the use of the Internet and the proliferation of other new media has revolutionised the advertising industry. The following question was posed to the interviewees, "How credible is traditional media for the promotion of tourism in this digital age?" With regards to this, the following sub-themes were identified. 


\subsection{Tourists'Attitude Towards Traditional Media}

It was apparent that the attitude of domestic tourists towards traditional media is different from the attitude of foreign tourists. Domestic tourists have a positive attitude towards traditional media than international tourists who are more inclined to online media. One interviewee explained that:

Foreign source markets are more digitally minded but we don't know whether they are using our data or they are using brochures or maps that are physically printed when they come here.

From the ongoing theme, one participant further explained that:

In terms of the domestic market, one will think that everyone is on cell phone, but there is still quite a majority who relies on traditional media such as brochures, magazines, and maps.

The ongoing discussion shows that international visitors have a positive attitude to online media than traditional media and the opposite is equally true for domestic tourists.

\subsection{Impact of Traditional Media Content}

All participants agreed that traditional media is more credible than online media. The interviewer observed that in all their offices, travel agents, tourism authorities, and hotels keep displays of brochures which they all indicated to be on demand by visitors. This does not support a claim by Goyal and Sharma (2013: 46) that the Internet has shifted entirely the traditional manner in which tourism products were promoted and distributed. Most aspects on how tourism is promoted were not changed but newer ways were added to existing ones. This was further corroborated by one participant from the tourism authority who stated that:

Traditional media still does it. It's a lot more credible that what many people may think. People forget that yes we are in a digital age but there are still a number of travellers who are within a generational gap, who have no clue on how to use a cell phone to access Internet. That's why it is better to still maintain a database of traditional media to cater for that target market.

This point clearly showed that traditional media is still highly credible than the general perception of the people. The findings also reveal that traditional media is a lot more credible than online media. From traditional media, print was found to be more credible, followed by radio and TV respectively.

\subsection{The Future of Traditional Media}

To infer about the future of traditional media, the interviewees were asked, "How far do you agree with the notion that traditional media will sooner or later disappear completely?" No interviewee was in agreement with this notion. As such, it can be deduced that traditional media is not going anywhere and it's still working well alongside online media. There is no evidence that traditional media will disappear completely, either sooner or later. One interviewee avowed that as he vociferously spoke:

We won't be getting rid of traditional media any time soon in KZN but we do need to play more on the online space!

This is again in opposition to Bruhn et al (2012: 771) who predicted that traditional media will succumb to technology innovations that revolutionised the promotion industry. They fear that traditional media have entered a death spiral and are no longer competitive in doing meaningful business. They added that promotion through traditional media is already dead and the media will soon or later disappear completely. These findings disapprove that claim and that claim can possibly be dismissed as it does no tally with these findings from the tourism marketers at present. There are noticeable mismatches between the earlier predictions on the performance of traditional media in this digital age and its actual performance in the market.

\section{Implications of the Study}

This study illustrates that promotion is a key element in the tourism industry and unlike any other industry, tourism needs special attention because this sector is unique (Bricker and Donohoe, 2015: 101). Instead of promoting a simple product, tourism sells a place and all that it has to offer. This study is conducted to contribute to the existing knowledge about the credibility of traditional media and online media in promoting tourism in Durban. The study will be useful to various stakeholders involved in promoting tourism products in Durban as this study will act as a guide for making informed decisions on media selection. It is hoped that the results of this study can be manipulated by policy makers and broaden their understanding of the current insights on the performance of traditional media and online media in this ever-changing world of media. This contribution aims to improve the effectiveness of communication by ensuring that a good advertising message is conveyed in the right media in order to achieve the intended impact. The findings will improve research efforts towards gaining contemporary understanding of the advertising industry which is reported to have undergone radical revolution in the past decade. 


\section{Conclusion and Recommendations}

The quantitative findings reveal that traditional media is still effective and more credible for toursim information in the contemporary tourism marketing environment. Online media was found to be best for interacting with potential travellers and virtual friends, more efficient in reaching the global market and an excellent relationship building mechanism especially through interactions with tourists using social media. Both traditional media and online media are very influential in catching attention of the tourists, generating an interest to visit destinations, arousing a desire to travel, and leading them to take action of travelling to that destination. Traditional media still has a role to play. It has been observed that although online media has a massive audience, by any means it does not reach the entire world. Television, radio, brochures, magazines, billboards and newspapers are still very useful in reaching the other segments of the market.

The qualitative findings have revealed that tourism authorities and marketers use both traditional media and online media for the promotion of tourism and their media usage patterns show an increase in the use of online media and neither a decrease nor an increase in the use of traditional media. However, the uptake of digital revolution seems much slower in South Africa than other first world countries. Tourism authorities indicated that though their usage of online media is increasing, they are still using more of traditional media than online media at this stage. Traditional media is used to a greater extent and the print medium (brochures and magazines) is mainly used among traditional media outlets. Tourism marketers further indicated that they did not shift their focus from traditional media but they increased their use of online media whilst maintaining the trend on traditional media.

The participants indicated that international visitors have a positive attitude towards online media than traditional media while domestic tourists have a positive attitude towards traditional media than online media. Traditional media was revealed to be highly credible than the general perception of the people and it is a lot more credible than online media. The survival of traditional media is not threatened by online media and traditional media is still working well alongside online media. There was no evidence found that traditional media will become obsolete, either sooner or later. Traditional media was reported to be very effective in promoting tourism in Durban and that brochures are used the most, followed by billboards, radio and television respectively. Tourism marketers indicated that they have had more responses from traditional media than online media. Traditional media was revealed to be more effective in persuading people to visit a destination than online media.

The researchers therefore, recommended that tourism marketers should, by any means, underestimate the role of traditional media in the promotion of their destinations. The domestic market, which also constitutes the bulk of the tourists visiting Durban, still relies heavily on traditional media than online media. As a result, marketers should continue to use traditional media to promote domestic tourism because of its sheer volume and its benefits for sustainability and seasonality. Marketers need to increase their presence online without neglecting the use of traditional media. Online media emerged as a new media with better efficiency than traditional media on certain dimensions such as interactivity and ability to reach the global market. As a result, it must be fully embraced because tourism is a global business. The study recommends tourism marketers and authorities to improve their uptake of the Internet and to be more innovative online so as to cater for the needs of the customers whose preference is online media. All media, traditional or none-traditional should be used for the promotion of tourism. There is no need to rely on one media to do it all. The world is communication-saturated so it takes many touch points to be noticed in the market. Where traditional media lacks, online media must be there to make up the difference and enhance the tourist's experience.

\section{Reference}

Bricker, K., \& Donohoe, H. (2015). Demystifying theories in tourism research. CABI. https://doi.org/10.1079/9781780647227.0000

Bruhn, M., Schoenmeuller, V., \& Schafer, D. B. (2012). Are social media replacing traditional media in terms of brand equity creation. Management Research Review (online), 35(9), 770-790. Available: www.emeraldinsight.com/2040-8269.htm (Accessed 15 April 2016). https://doi.org/10.1108/01409171211255948

Bujdosó, Z., Manhas, P. S., Dávid, L., \& Nedelea, A. (2014). Application Of Promotion Tools In Hospitality And Tourism Industry And Its Role In Developing The Jammu And Kashmir As A Tourist Destination. Revista de turism-studii si cercetari in turism, (18), 37-43.

Burrow, J. L. (2006). Marketing. $2^{\text {nd }}$ ed. Ohio: Thomson South-Western.

Chao, C. N., Corus, C., \& Li, T. (2012). Balancing traditional media and online advertising strategy. International Journal of Business, Marketing, and Decision Sciences, 5(1), 12-24.

Cooper, C. (2012). Essentials of Tourism. London: Pearson Education Limited. 
Cooper, C., \& Hall, C. M. (2016). Contemporary Tourism. An International approach. 3d ed. London: Good fellow Publishers Limited.

Dahlén, M., \& Edenius, M. (2007). When is advertising advertising? Comparing responses to non-traditional and traditional advertising media. Journal of Current Issues \& Research in Advertising, 29(1), 33-42. https://doi.org/10.1080/10641734.2007.10505206

Dickman, S., \& Maddock, M. (2000). The business of bed and breakfast. Melbourne: Hospitality Press.

Goyal, N., \& Sharma, S. K. (2013). USE OF GOVERNMENT TOURISM WEBSITES AS A TOOL FOR PROMOTING TOURISM. International Journal of Hospitality \& Tourism Systems, 6(2).

Gravetter, F. J., \& Farzano, L. B. (2011). Research methods to the behavioural sciences, $4^{\text {th }}$ ed. Belmont: Cengage Learning.

Hartl, A. (2002). Developing marketing strategies for tourism destinations in peripheral areas of Europe: The case of Bornholm. Bournemouth University.

Howison, S., Finger, G., \& Hauschka, C. (2015). Insights into the Web presence, online marketing, and the use of social media by tourism operators in Dunedin, New Zealand. Anatolia, 26(2), 269-283. https://doi.org/10.1080/13032917.2014.940357

Howitt, D., \& Cramer, D. (2010). Introduction to research methods in psychology, 3rd edition. London: Pearson.

Hoyle, L. H. (2002). Event Marketing. How to successfully promote events, festivals, conventions, and expositions. New York: John Wiley and Sons.

Hudson, S., \& Thal, K. (2013). The impact of social media on the consumer decision process: Implications for tourism marketing. Journal of Travel \& Tourism Marketing, 30(1-2), 156-160. https://doi.org/10.1080/10548408.2013.751276

Kardaras, D. K., Karakostas, B., \& Mamakou, X. J. (2013). Content presentation personalisation and media adaptation in tourism web sites using Fuzzy Delphi Method and Fuzzy Cognitive Maps. Expert Systems with Applications, 40(6), 2331-2342. https://doi.org/10.1016/j.eswa.2012.10.031

Kim, C. M. (2016). Social media campaigns: Strategies for public relations and marketing. New York: Routledge. https://doi.org/10.4324/9781315652375

Leiper, N. (1979). The framework of tourism: Towards a definition of tourism, tourist, and the tourist industry. Annals of tourism research, 6(4), 390-407. https://doi.org/10.1016/0160-7383(79)90003-3

Liu, Z. (2000). Internet tourism marketing: Potential Constraints. United Kingdom: University of Strathclyde.

Loda, M. D. (2014). Suggesting a more effective way to use the promotion mix in services. Services Marketing Quarterly (online), Quarterly: 304-320. Available: http://www.tandfonline.com/loi/wsmq20 (Accessed 04 June 2016). https://doi.org/10.1080/15332969.2014.946875

Nielsen, C. (2001). Tourism and the media. Australia: Hospitality Press.

Page, C., \& Meyer, D. (1999). Applied research design for business and management. McGraw-Hill Higher Education.

Pike, S. (2016). Destination Marketing Essentials. 2nd ed. New York: Routledge. https://doi.org/10.4324/9781315691701

Pomering, A., Noble, G., \& Johnson, L. W. (2011). Conceptualising a contemporary marketing mix for sustainable tourism. Journal of Sustainable Tourism, 19(8), 953-969. https://doi.org/10.1080/09669582.2011.584625

Sekaran, U., \& Bougie, R. (2010). Research methods of business: A skill building approach, $5^{\text {th }}$ ed. Chichester. John Wiley and Sons.

Seymour, J., Stolk, M., \& Kohler, K. (2009). A developer's guide to investing in tourism projects in KwaZulu-Natal. Tourism KwaZulu-Natal.

Statistics South Africa. (2016). Tourism. (online). Available www.statssa.gov.za/publications/Reports (Accessed 06 May 2016).

Sturgis, S. (2012). Are traditional media dead. Can journalism survive in the digital world. New York: The International Debate Education Associations.

Tourism Kwazulu-Natal. (2014). Statistics of our tourism sector 2014 (online), Available: http://www.zulu.org.za/files/images/files/140919080_TKZN\%20Stats\%20brochure_Lo.pdf (Accessed 02 October 2016). 
Van, C. N., \& Tu, L. T. (2016). Impact of e-commerce website on small tourism enterprises in quang binh, Vietnam. Journal of Asian Business Strategy, 6(10), 221. https://doi.org/10.18488/journal.1006/2016.6.10/1006.10.221.225

\section{Copyrights}

Copyright for this article is retained by the author(s), with first publication rights granted to the journal.

This is an open-access article distributed under the terms and conditions of the Creative Commons Attribution license which permits unrestricted use, distribution, and reproduction in any medium, provided the original work is properly cited. 